Article

\title{
Gold in Irish Coal: Palaeo-Concentration from Metalliferous Groundwaters
}

\author{
Liam A. Bullock ${ }^{1,2, * \mathbb{D}}$, John Parnell ${ }^{2}$, Joseph G.T. Armstrong ${ }^{2}$, Magali Perez ${ }^{2}$ and Sam Spinks ${ }^{3}$ \\ 1 Ocean and Earth Science, National Oceanography Centre Southampton, University of Southampton \\ Waterfront Campus, European Way, Southampton SO14 3ZH, UK \\ 2 Department of Geology \& Petroleum Geology, Meston Building, University of Aberdeen, King's College, \\ Aberdeen AB24 3UE, UK; j.parnell@abdn.ac.uk (J.P.); joseph.armstrong@abdn.ac.uk (J.G.T.A.); \\ magaliperez31@gmail.com (M.P.) \\ 3 CSIRO Mineral Resources, Australian Resources Research Centre (ARRC), 26 Dick Perry Avenue, \\ Kensington, WA 6151, Australia; sam.spinks@csiro.au \\ * Correspondence: L.A.Bullock@soton.ac.uk
}

Received: 25 June 2020; Accepted: 15 July 2020; Published: 17 July 2020

check for updates

\begin{abstract}
Gold grains, up to $40 \mu \mathrm{m}$ in size and containing variable percentages of admixed platinum, have been identified in coals from the Leinster Coalfield, Castlecomer, SE Ireland, for the first time. Gold mineralisation occurs in sideritic nodules in coals and in association with pyrite and anomalous selenium content. Mineralisation here may have reflected very high heat flow in foreland basins north of the emerging Variscan orogenic front, responsible for gold occurrence in the South Wales Coalfield. At Castlecomer, gold (-platinum) is attributed to precipitation with replacive pyrite and selenium from groundwaters at redox interfaces, such as siderite nodules. Pyrite in the cores of the nodules indicates fluid ingress. The underlying Caledonian basement bedrock is mineralised by gold, and thus likely provided a source for gold. The combination of the gold occurrences in coal in Castlecomer and in South Wales, proximal to the Variscan orogenic front, suggests that these coals along the front could comprise an exploration target for low-temperature concentrations of precious metals.
\end{abstract}

Keywords: coal; gold; platinum; groundwater; siderite; pyrite; Variscan orogeny; Ireland

\section{Introduction}

Much of the world's resources of gold and other precious metals occur in magmatic and metamorphic "basement" rocks. The gold deposits may be located following detection of anomalies in stream sediment and water samples, especially in terrains where bedrock exposures can be very limited [1]. However, the mobility of gold indicated by the water-borne anomalies implies that gold is also susceptible to concentration in sedimentary geochemical or hydrodynamic traps, such as in coal-forming settings [2]. Coal-hosted gold mining first took place over a century ago in the USA [3], with a renewed interest in coals and associated derivatives taking place in recent years [4-8]. There are numerous records of gold mineralisation within coal [2,5-23]. Concentrations of gold-bearing Upper Carboniferous coals have been identified in the US Appalachians [9,10], Canada [11], Great Britain [12,13], France [14], Central Europe [15-17], Black Sea [18], Ukraine and Russia [19-21], Central Asia [22] and China [7,23,24]. These include enrichments of gold above global averages in coal (0.003-0.0044 ppm [25]), and discrete occurrences of gold grains and gold-bearing minerals. Anomalous concentrations of gold in coal have a potentially high significance because large quantities of coal are converted to ash in power stations, and thereby concentrates of trace elements become available as a by-product [26-28]. This processing could yield economically viable gold.

In Great Britain, the discovery of gold in anthracitic coal in South Wales [12,13], often spatially associated with sulphide and selenide minerals, was accompanied by widespread speculation about 
coal as a source of precious metals. More recently, speculation has been renewed by claims of new technology for the extraction of gold from coal in Russia [20]. Since 2016, interest in gold and platinum occurrences in SE Ireland has been rejuvenated thanks to their discovery in stream sediments by the Geological Survey of Ireland's Tellus Programme.

In this study, microscopic observations and mineral associations (e.g., spatial and chemical relationships with siderite, pyrite and selenium) have been used to demonstrate the first known occurrence of platinumrich gold particulates within Carboniferous coals at Castlecomer, SE Ireland (Figure 1). We show that precious metal deposits in the Caledonian basement of SE Ireland are represented in mineralisation of coal in the cover succession. Anomalous concentrations of gold and platinum in modern stream samples imply similar mineralising groundwaters during the Carboniferous when the basement had been exhumed. These observations offer new prospects for exploration in SE Ireland, and in coalbearing strata and coal-hosted nodular mineralised zones worldwide.

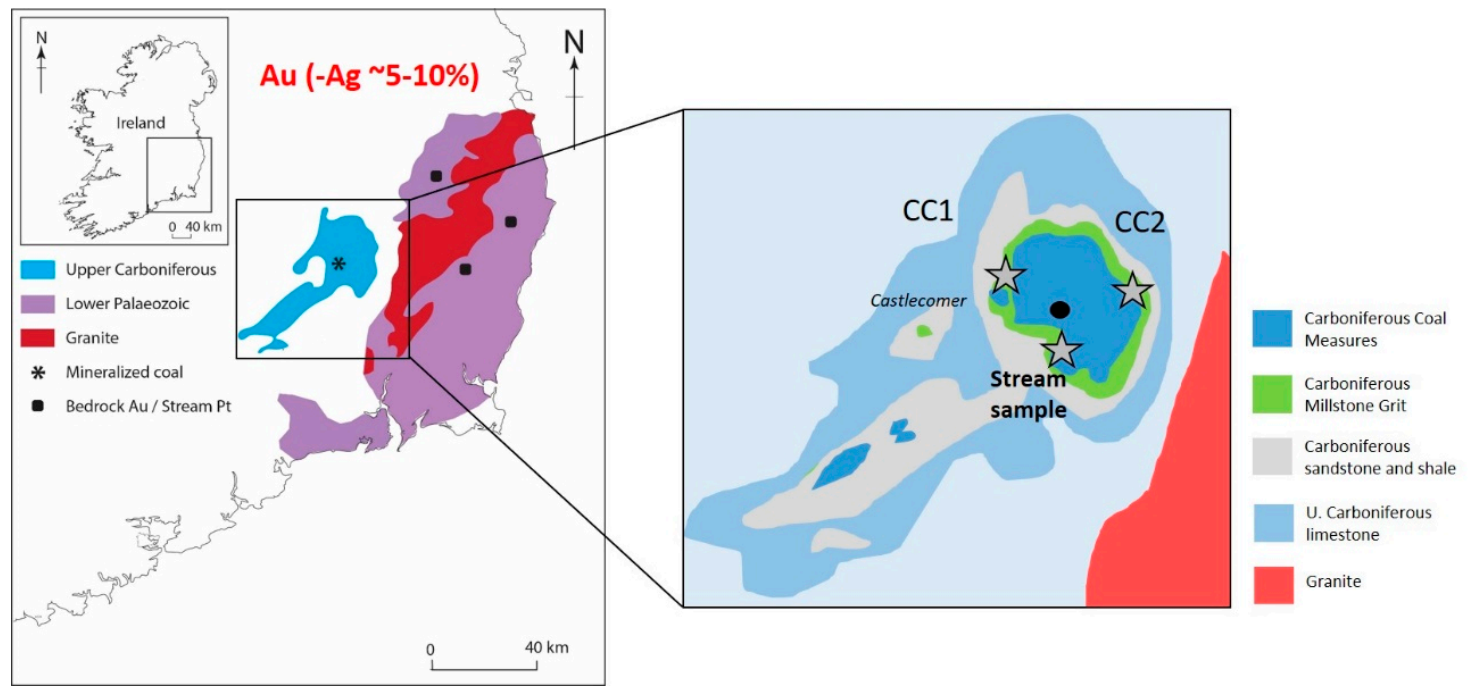

Figure 1. Location of the Castlecomer Plateau and Upper Carboniferous coal region, west of known goldhosting Lower Palaeozoic bedrock and gold-platinum-rich stream sediment localities. Gold-mineralised Irish Caledonides (containing both gold and silver, red text indicating the percentage of silver comprising the alloy [29]) were exposed and eroded into the sedimentary succession in advance of coal depositionThe provenance of Carboniferous rocks is dominated by this basement material. The sampling localities are indicated by grey stars.

\section{Gold in Global Coals}

The potential of coal and coal combustion products as a source of strategically and/or commercially valuable gold has been recently highlighted [2] in widespread Upper Carboniferous (313-304 Ma) coal deposits of the northern Hemisphere. Scarce but temporally related gold-bearing coals have been shown to coincide with the foreland and associated basins adjacent to the Variscan-Alleghanian Orogen. The $3000 \mathrm{~km}$ Variscan orogenic belt marks the collision of Laurussia with Gondwana, forming the supercontinent Pangea was marked by the Variscan Orogen [30]. The belt extends from the USA (Appalachia) to central Europe (Figure 2), with orogenesis and associated belts continuing eastwards to China [2]. The Variscan belt is characterised by proximal and extensive gold-mineralised zones. The west-east to northwest-southeast oriented orogenic belt was mineralised by gold ore from 410 to $310 \mathrm{Ma}$ [10], over 10,000 km from the Appalachians to China [2].

The age of mineralisation overlaps with Carboniferous basins receiving a very young component of detrital material from the orogenic front (less than $100 \mathrm{Ma}$ at time of deposition [2]). The rapidly eroding Variscan orogenic belt therefore provided an overlapping gold-fertile source to the newly depositing Upper Carboniferous sediments. Subsequently, gold is spatially concentrated by shear zone pathways parallel to (and proximal to) the belt. These gold occurrences are attributed to detritus associated with 
rapid erosion, and/or post-depositional hydrothermal mineralisation (e.g., enrichment by metal-rich fluid migration due to orogenic compression [31]). The high organic matter content of coals provided a chemical trap for gold liberated from the orogen [2]. Palaeoplacer gold, the product of mechanical erosion, also occurs in coal-bearing sequences in proximity to the orogenic front $[14,16,17,32]$. Such deposits result from the presence of the mineralised protolith, a sedimentary system that includes the erosion products from the protolith, a depositional foreland basin trap and subsequent preservation [2].

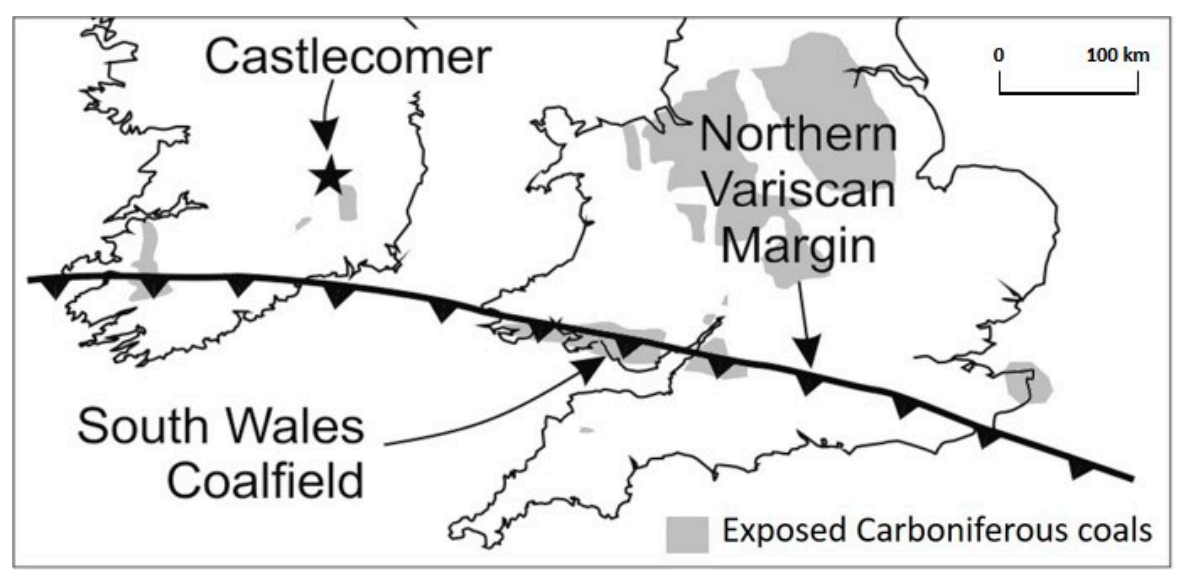

Figure 2. Setting of the Leinster Coalfield and South Wales Coalfield as basins north of the Variscan belt, modified from [33]. Gold associated with selenides, pyrite and siderite nodules have been previously recognised in the South Wales Coalfield [12,13,34], while Castlecomer coals of the Leinster Coalfield (sample area indicated by black star) are both pyritic and contain abundant siderite nodules [35].

\section{Study Site}

An anthracitic (high rank) belt of coal extends from the South Wales Coalfield, Great Britain, to the Leinster Coalfield, SE Ireland, adjacent to the Variscan orogenic front (Figures 1-3). These Upper Carboniferous coal deposits have a greater thermal maturity than other coals in Great Britain and Ireland [36,37]. Samples from the Leinster Coalfield represent coals of the Westphalian and Namurian (Figure 3a), deposited as basin sediments [35,38,39]. The Leinster Coalfield is the largest onshore coalfield in Southern Ireland, located in NW Co. Carlow, NE Co. Kilkenny and SE Co. Laois. The Coal Measures of the Castlecomer Plateau (Leinster Coalfield) formed from plant material in a swamp environment atop a massive delta. The $30 \mathrm{~cm}$ thick No. 2 horizon is the most economically important seam of the coalfield, historically worked in Castlecomer, while the Peacock Coal (0-20 cm thick), Stony Coal (0-20 cm), Double Seam $(0-20 \mathrm{~cm})$, Old 3 Foot Coal $(90 \mathrm{~cm})$, Jarrow Coal $(22-30 \mathrm{~cm})$, Wards Seam $(20-30 \mathrm{~cm})$ and No. 1 Coal $(0-20 \mathrm{~cm})$ horizons were also worked [38-40]. Castlecomer coals are generally anthracitic, though in some instances, coals of the Leinster coalfield have been classified as meta-anthracites, having undergone considerable thermal alteration [41]. This classification is reflected in the zones of increasing thermal maturity to the south of Ireland, delimited by vitrinite reflectance values in Carboniferous rocks (Figure 3b; [36]).

The descending series of the Castlecomer Plateau has a total thickness of $\sim 520 \mathrm{~m}$, and the series rests on top of the Leinster granite (Figure 3c; [39]). The regional geology exhibits a relatively uniform succession above Carboniferous limestone units, with the Castlecomer Plateau forming a basin (Figure 3c). The highest beds (characterised as "Stage F" in the descending section classification of [39]) are focused in the centre of the basin, with Middle Coal Measures of sandstone, shales and several coal seams (from the Jarrow Coal upwards). These beds are surrounded by "Stage E Gannister Beds" of grits, shales and thin coal seams, followed by "Stage D Flagstone Series" of sandstones and shales, "Stage C Shale Series" of grey sandy shales to dark shales and limestones, "Stage B" Carboniferous Upper, Middle and Lower Limestone and carbonaceous shales. The "Stage G" Upper Coal Measures are absent due to denudation [39]. 
a

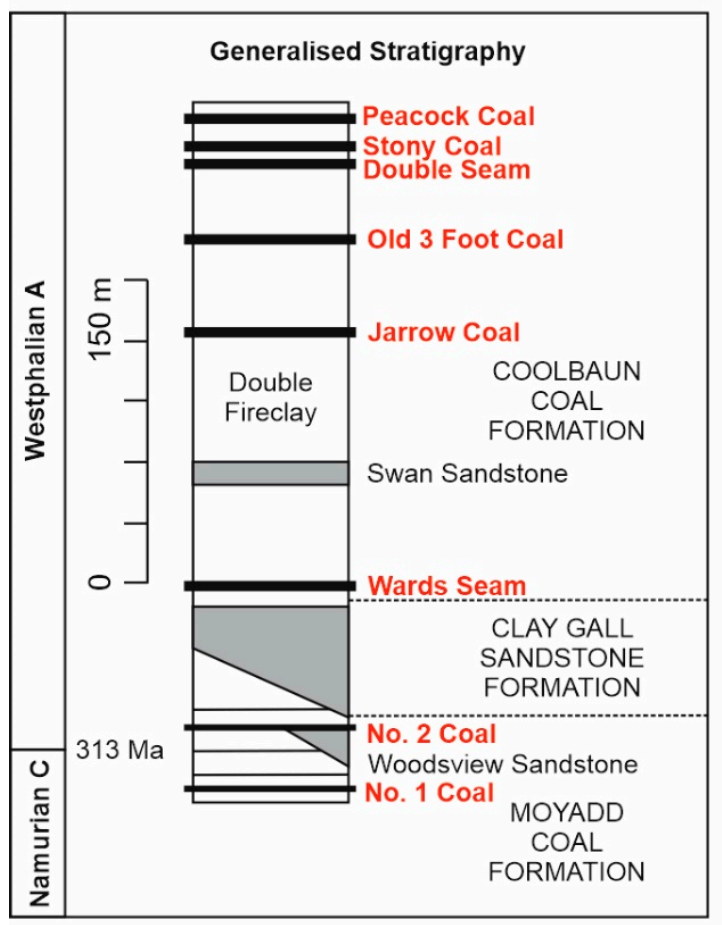

b

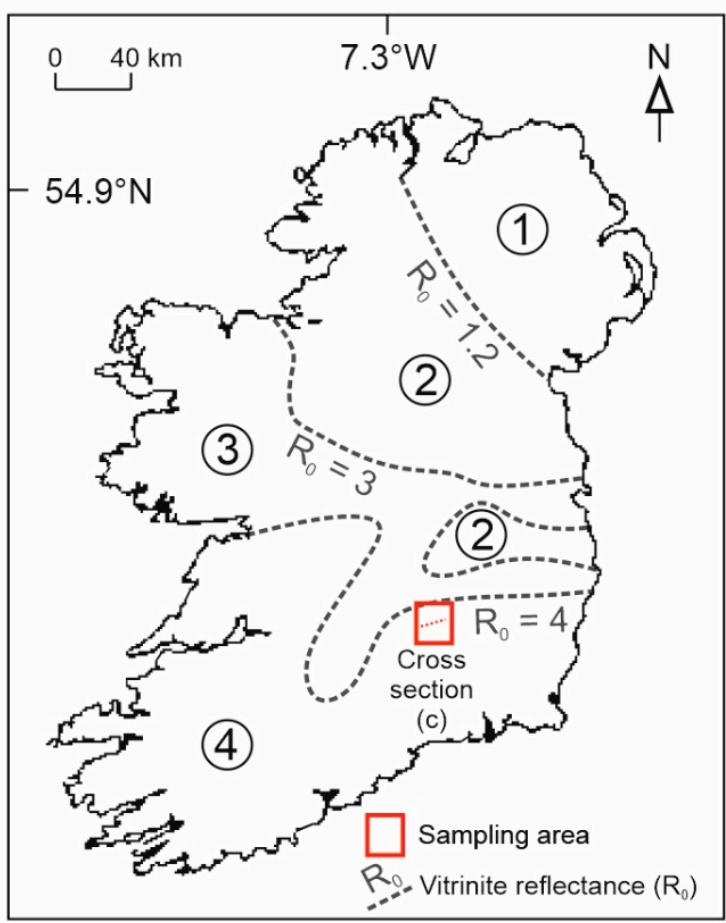

C

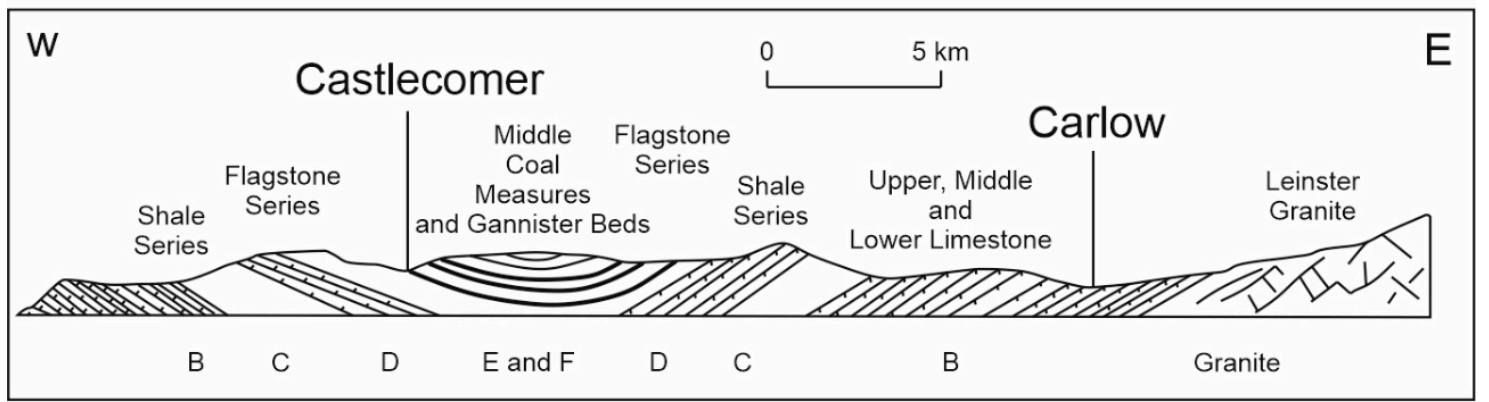

Figure 3. Regional geological setting of the Castlecomer Plateau study area in the Leinster Coalfield [35,36,38,39]. (a) Generalised stratigraphic section of the Castlecomer Plateau [38], including worked coal seams in the area (bold red text). (b) Map of Ireland showing coal sample study area, and division into zones $1-4$ of increasing thermal maturity, delimited by vitrinite reflectance $\left(R_{0}\right)$ values in Carboniferous rocks (simplified from [36]). (c) Section across the Leinster Coalfield, with Stages B-F classification of the series [39].

The presence of gold has not been previously reported in Irish coalfields. Gold was previously recorded in South Wales coals, accompanied by selenide minerals, on fracture surfaces of anthracite [12,13]. The gold-selenium mineralisation is described as a localised expression of more widespread sulphide-rich mineralisation in South Wales coal containing siderite nodules [34]. The Westphalian section in the vicinity of Castlecomer is both pyritic and contains abundant siderite nodules [36]. Therefore, we investigated the sideritic-pyritic coals of Castlecomer for evidence of mineralisation comparable to that in South Wales. Coal mining in Castlecomer has ceased, but coal seams and loose spoil, including sideritic nodules, can be sampled from former opencast mines and the River Dinin in and around the town of Castlecomer (Figure 4; Table 1). 


\section{Materials and Methods}

Coal samples $(n=9)$, including coals impregnated with nodular siderite, were collected from in situ seams, abandoned spoil heaps (Castlecomer Colliery and Bilboa Quarry) and stream sediment (River Dinin) in the former coal mining region of Castlecomer (Figure 4; Table 1). A suitable method for directly determining if gold is present and anomalous in coals as discrete particles is by direct identification using scanning electron microscopy with energy-dispersive X-ray spectroscopy (SEM-EDS) and laser ablation inductively coupled mass spectrometry (LA-ICP-MS) methods, as utilised in this study.
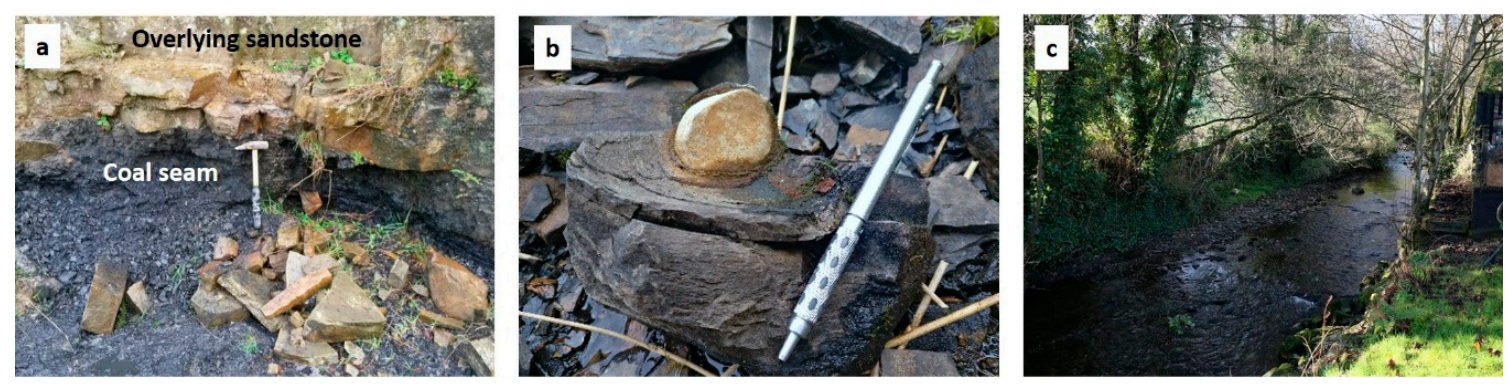

Figure 4. Sampling locations in the Castlecomer area of the Leinster Coalfield, County Kilkenny. (a) In situ coal seam and loose spoil at the abandoned Bilboa Quarry, Castlecomer. (b) Sideritic nodule hosted within coal (Bilboa Quarry). (c) The River Dinin, which flows through the former coal mining Castlecomer area, which hosts mineralised coal and siderite samples.

\subsection{Scanning Electron Microscopy (SEM-EDS)}

Whole rock samples were examined for gold particles using an ISI ABT-55 scanning electron microscope (SEM) (Kevex, Thermo Fisher Scientific, Waltham, MA, USA) with Link Analytical 10/55S EDAX (EDS) (Link An, High Wycombe, UK) facility at the University of Aberdeen.

\subsection{X-Ray Diffraction (XRD)}

X-ray diffraction (XRD) was performed on whole rock coal samples to determine individual mineralogical and compositional phases that otherwise cannot be determined by SEM-EDS. The finely powdered $(<64 \mu \mathrm{m})$ samples were placed on a flat disk sample holder, gently compressed and scanned on a Bruker D8 Discover diffractometer at the University of Aberdeen, using CuK $\alpha$ radiation and a scan range from $5^{\circ}$ to $90^{\circ}(2 \theta)$, a $0.03^{\circ}(2 \theta)$ step size and a data collection time of 10 s per step.

\subsection{Whole Rock and Sediment Geochemistry}

Whole rock coal samples were analysed by both inductively coupled plasma atomic emission spectroscopy (ICP-AES) and solution mass spectrometry (ICP-MS). The element of interest was the indicator selenium content (ppm), due to the association of gold and selenium in the South Wales Coalfield. Samples of $\sim 30 \mathrm{~g}$ were individually milled and homogenised, and $0.5 \mathrm{~g}$ were digested with aqua regia in a graphite heating block. The residue was diluted with deionised water $(18 \mathrm{MW} \mathrm{cm})$, mixed, and analysed using a Varian 725 instrument at ALS Minerals (Loughrea, Ireland; method ID: ME-MS41). Results were corrected for spectral inter-element interferences from the sample matrix, solvent medium, and plasma gas. Errors for whole rock for ICP-MS were calculated based on certified and achieved values for certified reference materials (CRM). Results for CRM analyses were within the anticipated target range for each metal and standard. Duplicate analyses produced reported values within the acceptable range for laboratory duplicates, with an average relative percent difference of $4 \%$. Total organic carbon (TOC) and sulphur contents were also measured using a LECO CS225 elemental analyser at the University of Aberdeen, to a precision of $\pm 0.05 \%$. Analyses were run concurrently with standards 501-024 (Leco Instruments, Saint Joseph, MI, USA) and BCS-CRM 362 (Bureau of Analysed 
Samples Ltd., Middlesbrough, UK). The repeatability (based on 3 repeats of standards and blanks) of samples was consistently within $1 \%$.

\subsection{Laser Ablation ICP-MS}

Trace element analysis of polished blocks was performed by using a New Wave laser ablation system UP213 nm (New Wave Research, Fremont, CA, USA) coupled to an ICP-MS Agilent 7900 (Agilent Technologies, Tokyo, Japan). The laser beam was fired with a spot size of $100 \mu \mathrm{m}$ moving in straight line, a $10 \mathrm{~Hz}$ repetition rate, and at $50 \mu \mathrm{m} \cdot \mathrm{s}^{-1}$ ablation speed with $1 \mathrm{~J} \cdot \mathrm{cm}^{2}$ energy. Before ablation, a warm-up of $15 \mathrm{~s}$ was applied with $15 \mathrm{~s}$ delay between each ablation. Settings parameters were optimised by using National Institute of Standards and Technology Glass 612 (NIST, Gaithersburg, MD, USA) to obtain the maximum sensitivity and ensure low oxide formation. In order to remove possible interferences which could affect selenium measurements, a reaction cell was used with hydrogen gas (between 3.0 and $3.5 \mathrm{~mL} / \mathrm{min}$ optimisation to decrease selenium background). MASS-1 synthetic polymetal sulphide (US Geological Survey, Reston, VA, USA) was used to provide a semi-quantification by calculating the ratio concentration $\left(\mu \mathrm{g} \cdot \mathrm{g}^{-1}\right) /$ counts per seconds and multiplying this ratio by the sample counts. Certified and informative values are available by request through the US Geological Survey website.

\section{Results}

Coals of the Leinster coalfield generally comprise up to $80 \%$ TOC (Table 1), with reported $89 \%$ vitrinite, $7.2 \%$ inertinite, $0.7 \%$ liptinite and $4.1-5.5 \%$ vitrinite reflectance, with 1.44 bireflectance [42,43]. Mineral content is generally low ( $3 \%$ mineral matter), with visible pyrite, nodular siderite and minor quartz present in samples. Qualitative XRD also reveals the presence of minor mixed clays and carbonates. Samples CC3-CC9 show visible replacive pyrite, conformable to bedding, and are impregnated with nodular siderite (CC5-CC9), containing fracture-filling pyritic septarian infills. Pyrite is evident sporadically in samples (typically from River Dinin samples) as anhedral grains (Figure 5) and within coal veins. Siderite nodules (Figure 5b) are hosted within the coal matrix. Electron microscope studies of rough and polished surfaces of the sideritic nodules showed that they are extensively mineralised by replacive pyrite (Figure $5 b$ ), and also by barite, xenotime, iron oxides and clay minerals. Pyrite in siderite nodules is part of the crack-fill septarian mineral assemblage (Figure 4b).

Discrete gold grains occur in pyrite within the siderite nodules (Figures 5 and 6, found in Bilboa quarry spoil heaps and River Dinin samples), and also within the coal matrix in (or in close proximity to) pyrite (Figure 5a,c). Gold grains are typically less than $10 \mu \mathrm{m}$ in length, though in some cases are up to $40 \mu \mathrm{m}$. Free gold grains are planar crystalline, sub-rounded and slightly elongate (Figure $5 \mathrm{~b}, \mathrm{c}$, and evident in EDS gold maps in Figure 6). Discrete gold phases were also identified by LA-ICP-MS (Figure 7). Bulk analysis of targeted pyrite-containing coal matrix areas $(\sim 2500 \mu \mathrm{m} \times \sim 2500 \mu \mathrm{m}$ flat surfaces) by LA-ICP-MS show an average gold content of 0.01 to $0.02 \mathrm{ppm}$ in two of the samples where gold was recognised (samples CC6 and CC7, see Table 1), above world average coal concentrations of 0.003 to $0.004 \mathrm{ppm}$ [25], while other samples did not contain gold above levels of detection ( $0.01 \mathrm{ppm}$ for LA-ICP-MS). Direct EDS spot analyses of the gold grains show that they contain variable percentages (5.3-18.6\%, mean $10.5 \%$ ) of admixed platinum, though the amount and particle sizes were too small to quantify the abundances within grains. No silver was detected, which thus cannot exceed $0.2 \%$. Direct EDS qualitative analysis also showed that gold grains also contain traces of copper (up to $0.3 \%$ ).

Measurements were made to test rigorously the genuine attribution of the gold to the Castlecomer samples, including:

(1) Gold was recorded in four distinct (sideritic and pyritic) samples by SEM-EDS and LA-ICP-MS analyses (Table 1).

(2) Gold was recorded on both polished and unpolished surfaces. 
(3) The composition of the gold is distinct from that of gold sputter coating used in the laboratory.

(4) No other gold-bearing material was prepared at the same time.

(5) The context of trace element sulphur in the gold is variable, suggesting that it is a natural precipitate rather than a man-made artefact.

Bulk ICP-MS analysis of the coal shows a mean selenium content of 9.7 ppm ( $\mathrm{n}=9$; Table 1), higher than the mean selenium content of British coals (2.1 ppm; [44]). Samples generally free of visible pyrite and siderite (CC1-CC2) contain 0.7 to $0.8 \mathrm{ppm}$ selenium, while pyritic coal samples contain 4.2 to $7.1 \mathrm{ppm}$ selenium and heavily pyritic-sideritic coal samples contain up to $25.8 \mathrm{ppm}$ selenium. Heavily pyritic-siderite nodular coal samples also contain up to $29.5 \%$ sulphur $(0.4 \%$ to $0.7 \%$ in the coal matrix) and TOC content below $40 \%$ (40\% to $80 \%$ in the coal matrix; Table 1). Sulphur and selenium concentrate in pyrite within veins in coal (Figure 5c), while possible discrete selenide "hot spot" phases were also identified within pyrite by LA-ICP-MS (Figure 7d).
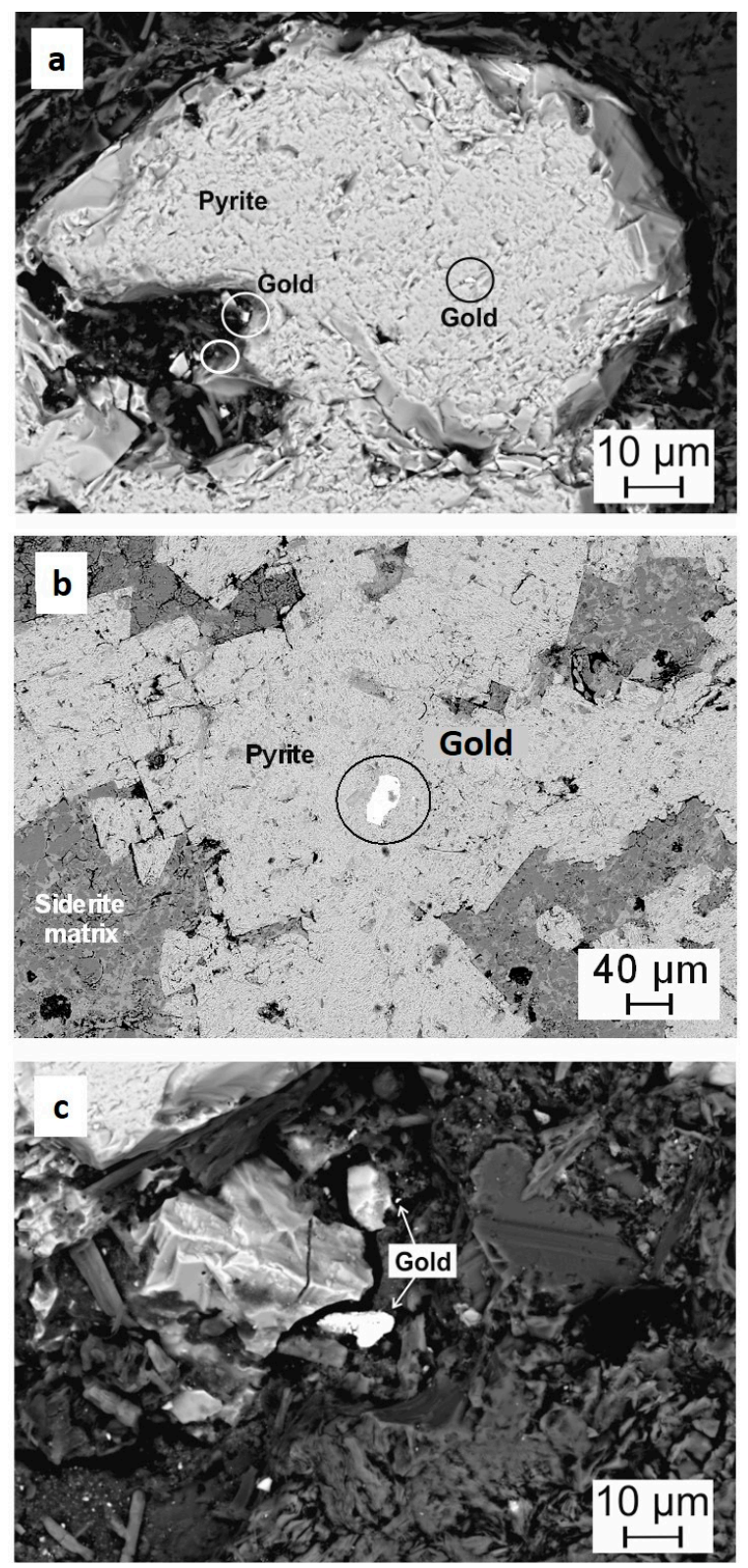

Figure 5. Mineralogy of Castlecomer coal samples. (a) Pyrite within the coal matrix (closely associated with a siderite nodule), containing discrete gold grains. (b) Siderite nodule with pyrite filling the septarian cracks, and a large gold grain present. (c) Gold grains at the edge of pyrite in coal. 

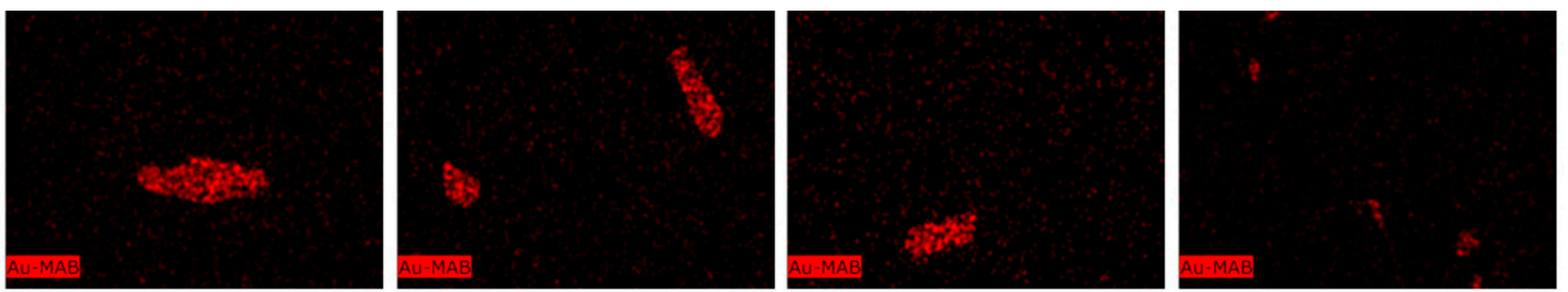

Figure 6. Energy-dispersive X-ray spectroscopy (EDS) element mapping images of gold (Au, high concentrations represented by red spots) grains in pyritic and sideritic Castlecomer coals. Maps are $50 \mu \mathrm{m} \times 50 \mu \mathrm{m}$ flat surfaces.

Table 1. Selenium (Se), gold, (Au), sulphur (S) and total organic carbon (TOC) content of Castlecomer coal samples. Locality information also shown, as well as a qualitative indication of presence of gold in each sample (based on SEM-EDS observations).

\begin{tabular}{|c|c|c|c|c|c|c|c|c|c|}
\hline Sample Code & Locality & Latitude & Longitude & Sample Description & Se (ppm) & Au (ppm) & $\mathrm{S}(\%)$ & TOC (\%) & $\begin{array}{c}\text { Gold Present } \\
\text { in Sample }\end{array}$ \\
\hline $\mathrm{CC} 1$ & Castlecomer & 52.813683 & -7.2049499 & Coal matrix (free of pyrite and siderite) & 0.7 & - & 0.4 & 77 & No \\
\hline $\mathrm{CC} 2$ & Bilboa quarry & 52.809600 & -7.022492 & Coal matrix (free of pyrite and siderite) & 0.8 & - & 0.4 & 80.1 & No \\
\hline $\mathrm{CC} 3$ & River Dinin & 52.805511 & -7.1924973 & Coal matrix (containing pyrite) & 7 & - & 0.7 & 64.4 & No \\
\hline $\mathrm{CC} 4$ & Castlecomer & 52.813683 & -7.2049499 & Coal matrix (containing pyrite) & 7.1 & - & 0.7 & 64.4 & No \\
\hline CC5 & River Dinin & 52.805511 & -7.1924973 & Coal matrix (containing pyrite and siderite) & 4.2 & 0.00 & 12.1 & 38.4 & Yes \\
\hline CC6 & River Dinin & 52.805511 & -7.1924973 & Sideritic coal (abundant pyrite and siderite) & 25.8 & 0.02 & 24.3 & 3.8 & Yes \\
\hline CC7 & River Dinin & 52.805511 & -7.1924973 & Sideritic coal (abundant pyrite and siderite) & 20.5 & 0.01 & 29.5 & 3.9 & No \\
\hline $\mathrm{CC} 8$ & Bilboa quarry & 52.809600 & -7.022492 & Sideritic coal (abundant pyrite and siderite) & 9.9 & 0.00 & 25.1 & 37.5 & Yes \\
\hline CC9 & Bilboa quarry & 52.809600 & -7.022492 & Sideritic coal (abundant pyrite and siderite) & 11.2 & 0.00 & 12.3 & 27.6 & Yes \\
\hline
\end{tabular}


a

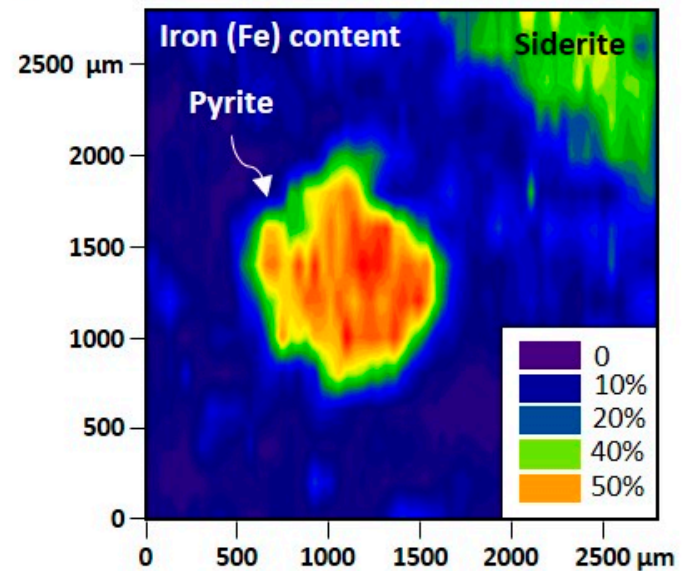

C

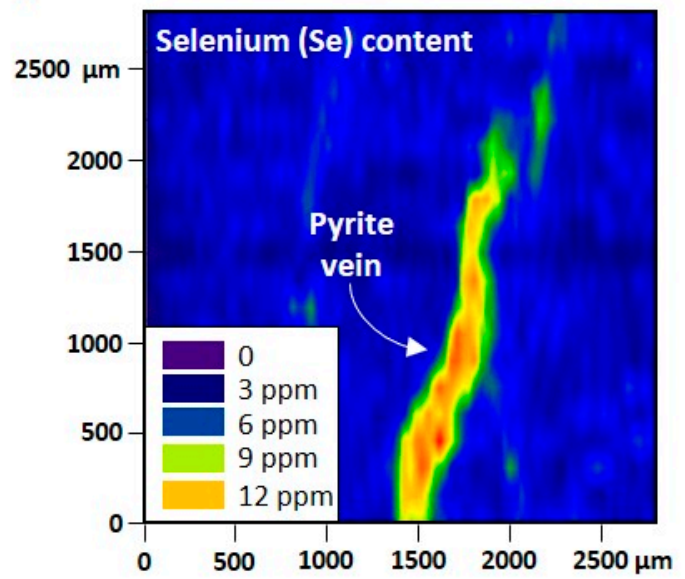

b

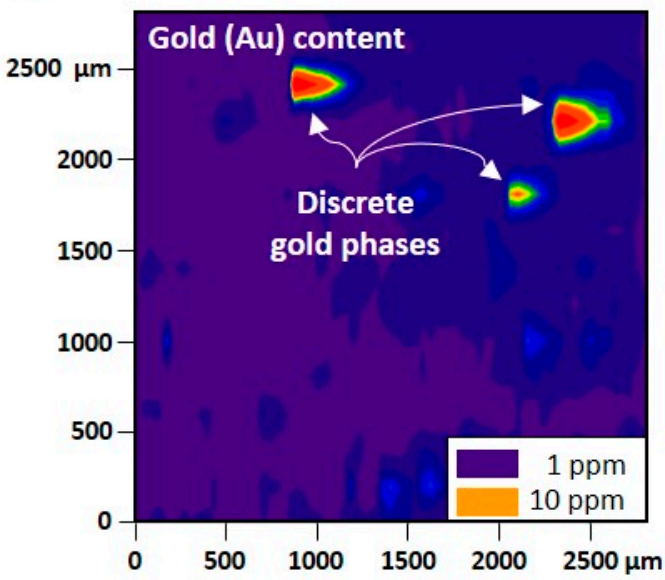

d

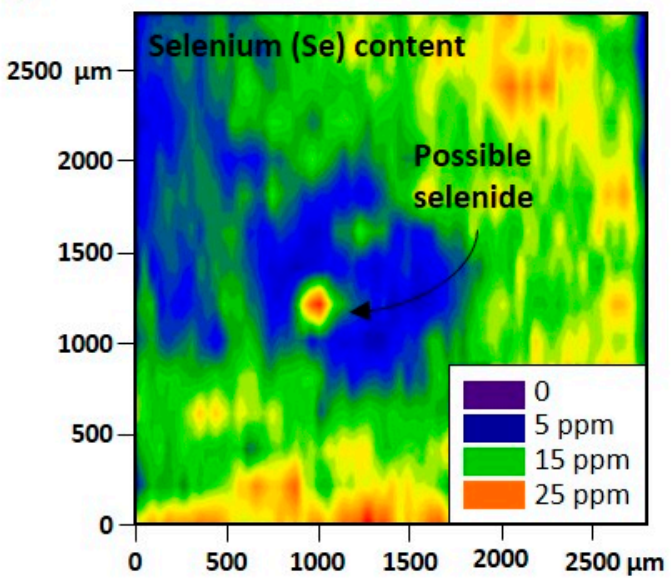

Figure 7. Laser ablation inductively coupled mass spectrometry (LA-ICP-MS) trace element maps of Castlecomer coal samples (CC6 and CC7). (a) High iron content indicating the presence of microscopic pyrite and siderite in coal (CC6). (b) Discrete gold phases (with silver absent) in association with pyrite and siderite (same area analysed as (a)). (c) Selenium concentrated within pyritic vein in coal (CC7).

(d) Concentrated "hot spot" of selenium, indicating possible selenide within pyrite (CC6).

\section{Discussion}

\subsection{Conditions of Mineralisation}

The mineralisation in the Carboniferous coals at Castlecomer, as in several parts of the spatially and temporally correlative South Wales Coalfield, predominantly occurs in siderite nodules. The development of siderite nodules is a feature of burial diagenesis at depths down to a few hundred metres [45], in a non-marine environment, where iron is deposited as carbonates. Subsequent mineralisation by pyrite occurs replacively in septarian crack fills (Figure 5b). Siderite nodules in coals and organic-rich shales elsewhere are consistently mineralised at their cores by pyrite, base metal sulphides, barite and petroleum (e.g., [46]). These mineral occurrences indicate the ingress of fluid during burial (post-peat depositional diagenesis [47]), despite the low permeability of the nodules and their host rocks, with increasing thermal maturation (rank advance) and fluid migration through time. Selenium enrichment can also be attributed to such fluid ingress.

Data from South Wales suggest that mineralisation commenced at relatively low temperatures $\left(<100{ }^{\circ} \mathrm{C}\right.$; [48]), but at temperatures high enough $\left(>60^{\circ} \mathrm{C}\right)$ to explain the incorporation of migrated hydrocarbons within cracks [48]. It is speculated that these conditions were also prevalent in the Leinster Coalfield. Mineralisation of these basins, rather than other coal basins in Great Britain and Ireland, may 
have reflected the very high heat flow in foreland basins north of the emerging Variscan orogenic front. In South Wales, the geothermal gradient was calculated to be $45^{\circ} \mathrm{C} \mathrm{km}^{-1}$ [49]. Northward-directed flow away from the orogen controlled the formation of high rank anthracite and the distribution of mineralisation, as inferred for South Wales coal [31]. The Carboniferous coal at Castlecomer is also anthracitic, indicative of similarly high heat flow and similar potential for mineralisation.

The occurrence of gold in coals reported here contributes to growing evidence for the mobility of gold in the sedimentary environment (e.g., [50,51]). The subhedral, sub-rounded and planar nature of the gold grains suggests that they may have undergone some mechanical alteration after precipitation. A high proportion of gold in the northern hemisphere is in basement rocks (Caledonian basement and older), or in placers derived from those rocks. Many widespread coalfield areas are of Carboniferous-Permian age [52], and the provenance of Carboniferous rocks is dominated by the basement [53]. Thus, there is potential for concentrations of basement-derived metals within coal and coal combustion products. The purity of the coal-hosted gold in this study (inferred from EDS analysis) is high, and contrasts with much epigenetic gold which contains a greater proportion of alloyed silver and other trace elements. Analyses of gold in the bedrock of SE Ireland show silver contents often comprise 5-10\% of the alloy [29], compared to the $<0.2 \%$ silver component observed in this study. Such high purity is a feature of gold deposited in sedimentary systems, in which precious metals remobilised by the dissolution of older high-temperature deposits become fractionated during re-precipitation [54]. The precipitation of gold in sedimentary rocks is commonly redox-controlled and occurs as a trace component of pyrite. The focus of pyrite (and selenium, possibly as selenides) precipitation in siderite nodules has also made them a focus for gold precipitation.

\subsection{Gold (and Platinum) Source}

Gold and platinum are both mobile in surface environments, especially in acidic groundwaters, and their enrichment in peat [55] are analogous to their concentration in coal. Gold in coal may be attributed to a mixture of detrital matter and precipitation from groundwaters [2], and thus most likely to be found where gold ores occur in the bedrock source regions for the groundwaters. The same scenario could be envisaged for any platinum, which was detected as a mixed alloy in low concentrations with gold by EDS. Therefore, the occurrence of gold (-platinum) mineralisation in coal in a region where stream sediment sampling has identified these elements in anomalous concentrations suggests that groundwaters were the source. Thus, the knowledge that the gold-mineralised Leinster Massif region had been exhumed in advance of coal deposition makes such a provenance likely. The lack of silver in the coal-hosted gold, while the nearby bedrock gold consistently contains silver, is indicative of authigenic gold precipitation from groundwaters rather than detrital gold [56].

The Lower Palaeozoic rocks of SE Ireland are a known source of gold [57], and related placer gold was the cause of a celebrated gold rush in 1795 [58]. To the southwest, the Devono-Carboniferous Munster Basin also contains showings of gold in hydrothermal veins [59], the source of which is not clear but indicates a protolith somewhere in the region. Provenance studies in the Devono-Carboniferous rocks of England and Ireland indicate that the Irish Caledonides were exposed and eroded into the sedimentary succession [53]. Notably, the Devonian deposits of SW Ireland contain clasts of tourmalinite [60], associated with gold mineralisation in the Leinster Massif [61]. There was, therefore, gold in the surface environment at that time. The source for the gold in South Wales could also be SE Ireland, but palaeocurrent data for the South Wales Coalfield allow possible derivation from regions spanning Nova Scotia, Ireland, Wales and France [62], all of which had been recently mineralised by gold [10]. There was, therefore, a good chance of gold availability to coal-forming environments along the Variscan orogenic front.

Gold with platinum is a rare alloy in nature, but in this case reflects the elements available in the groundwaters. Alloyed grains of gold and platinum, free of silver, may form from unrelated sources, and have been previously reported in neighbouring parts of the British Isles [63,64]. Alluvial gold alloy grains that contain no silver, but do contain high selenium, platinum and copper, have been 
identified in Leadhills, Scotland, precipitated from a mineralising solution rich in these elements [63]. Gold enriched with platinum has also been identified in drainage and overburden derived samples from Lower Devonian sediments and in minor volcanic rocks of Devon, SW England, considered to have grown from oxidising saline fluids at approximately $100{ }^{\circ} \mathrm{C}$ [64]. Gold-platinum-copper alloys have also been described in Russia $[65,66]$ in the placer of the Konder alkaline-ultrabasic massif [65] and in the alluvium along the River Bolshoy Khailyk, western Sayans [66]. Although rare, platinum enrichments are recorded in coal where a source is available [9]. As in the case of gold, the rocks of SE Ireland are anomalously rich in platinum, evidenced by stream sediment surveys, provisionally identified in placer sands worked during the gold rush [67]. Data for the 90th percentile of stream sediment compositions show a gold/platinum ratio of $\sim 8$, comparable to the ratio measured in the coal-hosted gold. We note incidentally that the occurrence of platinum is a matter of contention in determining the origin of Irish gold artefacts, some of which contain trace platinum [68], and it is assumed that Irish gold contains no platinum [29].

\subsection{Wider Exploration Implications}

The high tonnages of coal and the pre- and post-combustion waste derivatives (e.g., coal ash, $[8,20,69]$ ) make coal a potentially valuable and underexplored resource for gold and other economic elements globally, warranting further consideration. Available literature data for gold in coal are limited due to a lack of focus on the viability of the setting and subsequent low detection limits utilised in analytical studies (e.g., $0.2 \mathrm{ppm}$ ). However, discrete gold particles are susceptible to "the nugget effect" during analysis, where particles are either present or missing in a given sample, meaning estimates may be overor under-valued. Consequently, elemental proxies or "pathfinder" indicator elements are commonly targeted for gold identification and exploration purposes (e.g., arsenic, antimony, mercury, selenium, tellurium). Coal containing $\sim 0.05$ ppm noble metals (typically $50 \%$ as gold) may be considered as a potential ore [8]. The lack of analytical focus on gold in Carboniferous coals means that the globally extensive basin outcrops likely contain further instances of gold occurrences, possibly of economic significance. The time and financial implications of undertaking qualitative, semi-quantitative and quantitative analysis on whole rock coal samples means that dedicated gold exploration in coals is not viable, and the closure of the coal mines in regions such as Castlecomer means that mining, production and storage are now absent in many regions. However, by targeting specific coalfield regions that show indicators of gold potential in active coal mining regions worldwide, such as those that have known pyrite and siderite occurrence, high pathfinder element concentrations, proximity to the Variscan orogenic front and/or a proximity to gold-mineralised protoliths, investigations may become more focused. More practically, coal combustion products of power stations may contain elevated concentrations of gold, platinum and other trace elements of economic importance. As the global coal industry continues to grow [70], the necessity to find added value in the waste derivatives will become increasingly important. This is particularly pertinent for the recovery of critical trace elements used in nanotechnologies [71-73], or toxic trace elements that may impact the environment [74-76]. Siderite is mostly separated and removed during coal processing, meaning it is not burned with coal, and any associated trace elements would not reach the fly ash post-combustion stage. If siderite and pyrite mineral matter from coal can be removed and recovered during the early stages of processing, it may represent a unique concentrated resource for gold and other elements of economic importance.

\section{Conclusions}

Native gold is recorded within Carboniferous coals of the Leinster Coalfield at Castlecomer, SE Ireland, for the first time. The geochemical characteristics of the gold provide evidence for its origin:

- The gold occurs adjacent to a region where the Caledonian basement bedrock is mineralised by gold, thus a demonstrable source is available.

- The gold does not contain detectable silver, so could not represent detrital gold from the bedrock gold mineralisation and instead implies precipitation from groundwaters. 
- The consistent enrichment in platinum in the gold suggests precipitation from groundwaters, whose present-day equivalents are also enriched in both gold and platinum.

- The enrichment of selenium in the coal is corroborating evidence for the flow of groundwaters through the coal.

The combination of the gold occurrences in coal in Castlecomer and in South Wales, both proximal to the Variscan orogenic front, suggests that coals along the front could constitute an exploration target for low-temperature concentrations of precious metals.

Author Contributions: Conceptualisation, L.A.B. and J.P.; methodology and formal analysis, L.A.B., J.G.T.A. and M.P.; sample collection, L.A.B., J.G.T.A. and S.S.; writing-original draft preparation, L.A.B.; project administration and funding acquisition, J.P. All authors have read and agreed to the final version of the manuscript.

Funding: The project was supported by the NERC Security of Supply programme (grant NE/L001764/1).

Acknowledgments: The authors wish to thank John Still and Colin Taylor of the University of Aberdeen for their technical support. The authors wish to thank Shifeng Dai and David French for their editorial work, and two anonymous reviewers for their critical comments which greatly improved the manuscript.

Conflicts of Interest: The authors declare no conflict of interest.

\section{References}

1. Coker, W.B.; Shilts, W.W. Geochemical exploration for gold in glaciated terrain. In Gold Metallogeny and Exploration; Foster, R.P., Ed.; Springer: Dordrecht, The Netherlands, 1991; pp. 336-359.

2. Parnell, J. Variscan cycling of gold into a global coal reservoir. Ore Geol. Rev. 2019, 114, 103158. [CrossRef]

3. Jenney, W.P. Field observations in the Hay Creek coal field. US Geol. Surv. 19th Ann. Rep. 1903, 2, 568-593.

4. Seredin, V.; Finkelman, R.B. Metalliferous coals: A review of the main genetic and geochemical types. Int. J. Coal Geol. 2008, 76, 253-289. [CrossRef]

5. Sorokin, A.P.; Kuz'minykh, V.M.; Rozhdestvina, V.I. Gold in brown coals: Localization conditions, modes of occurrence, and methods of extracting. Dokl. Earth Sci. 2009, 424, 109-113. [CrossRef]

6. Wang, W.F.; Qin, Y.; Sang, S.X.; Wang, J.Y.; Wang, R. Advances in geochemical research on gold in coal. J. China Coal Soc. 2010, 35, 236-240.

7. Dai, S.; Wang, X.; Seredin, V.V.; Hower, J.C.; Ward, C.R.; O’Keefe, J.M.K.; Huang, W.; Li, T.; Li, X.; Liu, H.; et al. Petrology, mineralogy, and geochemistry of the Ge-rich coal from the Wulantuga Ge ore deposit, Inner Mongolia, China: New data and genetic implications. Int. J. Coal Geol. 2012, 90-91, 72-99. [CrossRef]

8. Chelgani, S.C.; Hower, J.C. Relationships between noble metals as potential coal combustion products and conventional coal properties. Fuel 2018, 226, 345-349. [CrossRef]

9. Chyi, L.L. The distribution of gold and platinum in bituminous coal. Econ. Geol. 1982, 77, 1592-1597. [CrossRef]

10. Romer, R.L.; Kroner, U. Paleozoic gold in the Appalachians and Variscides. Ore Geol. Rev. 2018, 92, 475-505. [CrossRef]

11. Zodrow, E.L. Geochemical trends in whole-seam coal channel samples from the Sydney Coalfield (Upper Carboniferous), Nova Scotia, Canada. Marit. Sed. Atlantic Geol. 1987, 23, 141-150. [CrossRef]

12. Gayer, R.A.; Rickard, D. Gold in South Wales coal. Nature 1993, 364, 395. [CrossRef]

13. Gayer, R.A.; Rickard, D. Colloform gold in coal from southern Wales. Geology 1994, 22, 35-38. [CrossRef]

14. Bouchot, V.; Ledru, P.; Lerouge, C.; Lescuyer, J.-L.; Milesi, J.-P. Late Variscan mineralizing systems related to orogenic processes: The French Massif Central. Ore Geol. Rev. 2005, 27, 169-197. [CrossRef]

15. Bielowicz, B.; Misiak, J. The forms of occurrence and geochemistry of sulphides in hard coal deposits of the Libiaż̇ Beds in the Upper Silesian Coal Basin, Southern Poland. Geol. Geophys. Environ. 2017, 43, 109-125. [CrossRef]

16. Klominsky, J.; Klener, J.; Novak, F.; Malec, J.; Kvacek, M. Fossil gold placers in the Carboniferous near Krivce (western Bohemia). Cas. Mineral. Geol. 1979, 24, 291-300.

17. Malec, J.; Veselovsky, F.; Bohmova, V.; Prouza, V. Jacutingaite, palladian gold and Pd-selenide in the copper ore from Carboniferous sediments by Kostalov near Semily (Krkonose Piedmont Basin, Czech Republic). Geosci. Res. Rep. 2011, 189-192.

18. Eskenazy, G.M. Trace elements geochemistry of the Dobrudza coal basin, Bulgaria. Int. J. Coal Geol. 2009, 78, 192-200. [CrossRef] 
19. Arbuzov, S.I.; Rikhvanov, L.P.; Maslov, S.G.; Arhipov, V.S.; Belyaeva, A.M. Anomalous gold contents in brown coals and peat in the south-eastern region of the Western-Siberian platform. Int. J. Coal Geol. 2006, 68, 127-134. [CrossRef]

20. Rozhdestvina, V.I.; Sorokin, A.P.; Kuz'minykh, V.M.; Kiseleva, A.A. A gold content in brown coal and combustion products. J. Min. Sci. 2011, 47, 842-849. [CrossRef]

21. Seredin, V.V. Distribution and formation conditions of noble metal mineralization in coal-bearing basins. Geol. Ore Deposits 2007, 49, 1-30. [CrossRef]

22. Levitan, G. Gold Deposits of the CIS; Xlibris Publishing: Bloomington, IN, USA, 2008.

23. Nie, A.; Mei, S.; Guan, D.; Wu, P.; Zhang, Z. A study on the genetic relations between Permian Longtan Formation coal series strata and Carlin-type gold deposits, southwestern Guizhou Province, China. Chin. J. Geochem. 2008, 27, 291-298. [CrossRef]

24. Seredin, V.V.; Dai, S. The occurrence of gold in fly ash derived from high-Ge coal. Miner. Depos. 2014, 49, 1-6. [CrossRef]

25. Ketris, M.P.; Yudovich, Y.E. Estimations of Clarkes for Carbonaceous biolithes: World averages for trace element contents in black shales and coals. Int. J. Coal Geol. 2009, 78, 135-148. [CrossRef]

26. Seredin, V.V.; Dai, S.F.; Sun, Y.Z.; Chekryzhov, I.Y. Coal deposits as promising sources of rare metals for alternative power and energy-efficient technologies. Appl. Geochem. 2013, 31, 1-11. [CrossRef]

27. Sahoo, P.K.; Kim, K.; Powell, M.A.; Equeenuddin, S.M. Recovery of metals and other beneficial products from coal fly ash: A sustainable approach for fly ash management. Int. J. Coal Sci. Technol. 2016, 3, 267-283. [CrossRef]

28. Wang, W.; Sang, S.; Hao, W.; Wang, R.; Zhang, J.; Duan, P.; Qin, Y.; Xu, S. A cut-off grade for gold and gallium in coal. Fuel 2015, 147, 62-66. [CrossRef]

29. Chapman, R.J.; Leake, R.C.; Warner, R.A.; Cahill, M.C.; Moles, N.R.; Shell, C.A.; Taylor, J.J. Microchemical characterisation of natural gold and artefact gold as a tool for provenancing prehistoric gold artefacts: A case study in Ireland. Appl. Geochem. 2006, 21, 904-918. [CrossRef]

30. Simancas, J.F.; Tahiri, A.; Azor, A.; Lodeiro, F.G.; Poyatos, D.J.M.; El Hadi, H. The tectonic frame of the Variscan-Alleghanian orogeny in Southern Europe and Northern Africa. Tectonophysics 2005, 398, 181-198. [CrossRef]

31. Gayer, R.A.; Garven, G.; Rickard, D.T. Fluid migration and coal-rank development in foreland basins. Geology 1998, 26, 679-682. [CrossRef]

32. Mills, R.F. Parallels between paleoplacer development in northern Nova Scotia and southern New Brunswick. In Minerals and Energy Branch Report of Activities 1998; Nova Scotia Department of Natural Resources: Halifax, NS, Canada, 1999; pp. 61-68.

33. Hower, J.C.; Gayer, R.A. Mechanisms of coal metamorphism: Case studies from Paleozoic coalfields. Int. J. Coal Geol. 2002, 50, 215-245. [CrossRef]

34. Bevins, R.E.; Young, B.; Mason, J.S.; Manning, D.A.C.; Symes, R.F. Wales. In Mineralization of England and Wales (Geological Conservation Review Series); Joint Nature Conservation Committee: Peterborough, UK, 2010; Volume 36, pp. 199-381.

35. Nevill, W.E. The Millstone Grit and Lower Coal Measures of the Leinster Coalfield. Proc. R. Ir. Acad. B 1956, 58, 1-16.

36. Clayton, G.; Haughey, N.; Sevastopulo, G.D.; Burnett, R. Thermal Maturation Levels in the Devonian and Carboniferous Rocks in Ireland; Geological Survey of Ireland: Dublin, Ireland, 1989.

37. Bevins, R.E.; White, S.C.; Robinson, D. The South Wales Coalfield: Low grade metamorphism in a foreland basin setting? Geol. Mag. 1996, 133, 739-749. [CrossRef]

38. Higgs, K.T.; O'Connor, G. Stratigraphy and palynology of the Westphalian strata of the Leinster Coalfield, Ireland. Ir. J. Earth Sci. 2005, 23, 65-84. [CrossRef]

39. Hull, E. On the upper Limit of the essentially Marine Beds of the Carboniferous Group of the British Isles and adjoining Continental Districts: With suggestions for a fresh classification of the Carboniferous Series. Part II Irish Carboniferous Districts. Quart. J. Geol. Soc. London 1877, 33, 613. [CrossRef]

40. Hardman, E.T.; Baily, W.H. Explanatory Memoir on the Geology of the Leinster Coalfield; British Geological Survey: Keyworth, UK, 1881; p. 95.

41. Misz, M. Characteristics of coals from the Leinster Coalfield (Ireland); Part 1, Geology of coals from the Leinster Coalfield. Pr. Geol. UŚl. 1997, 14, 28-44. 
42. Misz, M. Characteristics of coals from the Leinster Coalfield (Ireland); Part 2, Characteristic of anthracites from the Leinster Coalfield. Geologia (Katowice) 2002, 15, 95-110.

43. Kwiecińska, B.; Pusz, S.; Duber, S. Petrographical study of anthracites from European coal basins. Pol. Geol. Inst. Spec. Pap. 2002, 7, 149-158.

44. Bullock, L.A.; Parnell, J.; Feldmann, J.; Armstrong, J.G.T.; Henn, A.S.; Mesko, M.F.; Mello, P.A.; Flores, E.M.M. Selenium and tellurium concentrations of Carboniferous British coals. Geol. J. 2018, 1, 1-12. [CrossRef]

45. Young, T. Sedimentary iron ores. In Mineralization in the British Isles; Pattrick, R., Polya, D., Eds.; Chapman and Hall: London, UK, 1993; pp. 446-489.

46. Alderton, D.H.M.; Bevins, R.E. P T conditions in the South Wales Coalfields: Evidence from co-existing hydrocarbon and aqueous fluid inclusions. J. Geol. Soc. Lond. 1996, 153, 265-275. [CrossRef]

47. Dai, S.; Bechtel, A.; Eble, C.F.; Flores, R.M.; French, D.; Graham, I.T.; Hood, M.M.; Hower, J.C.; Korasidis, V.A.; Moore, T.A.; et al. Recognition of peat depositional environments in coal: A review. Int. J. Coal Geol. 2020, 219, 103383. [CrossRef]

48. Alderton, D.H.M.; Oxtoby, N.; Brice, H.; Grassineau, J.N.; Bevins, R.E. The link between fluids and rank variation in the South Wales Coalfield: Evidence from fluid inclusions and stable isotopes. Geofluids 2004, 4, 221-236. [CrossRef]

49. Firth, J.N.M.; Eglinton, G. Hatchettine from the South Wales Coalfield. In Advances in Organic Geochemistry; Pergamon: Oxford, UK, 1972; pp. 613-628.

50. Youngson, J.; Craw, D. Recycling and chemical mobility of alluvial gold in Tertiary and Quaternary sediments, Central and East Otago, New Zealand. N. Zeal. J. Geol. Geop. 1996, 39, 493-508. [CrossRef]

51. Sanyal, S.K.; Shuster, J.; Reith, F. Cycling of biogenic elements drives biogeochemical gold cycling. Earth Sci. Rev. 2019, 190, 131-147. [CrossRef]

52. Cleal, C.J.; Thomas, B.A. Palaeozoic tropical rainforests and their effect on global climates: Is the past the key to the present? Geobiology 2005, 3, 13-31. [CrossRef]

53. Morton, A.; Waters, C.; Fanning, M.; Chisholm, I.; Brettle, M. Origin of Carboniferous sandstones fringing the northern margin of the Wales-Brabant Massif: Insights from detrital zircon ages. Geol. J. 2015, 50, 553-574. [CrossRef]

54. Webster, J.G.; Mann, A.W. The influence of climate, geomorphology and primary geology on the supergene migration of gold and silver. J. Geochem. Explor. 1984, 22, 21-42. [CrossRef]

55. Dissanayake, C.B.; Kritsotakis, K. The geochemistry of Au and Pt in peat and algal mats-A case study from Sri Lanka. Chem. Geol. 1984, 42, 61-76. [CrossRef]

56. Santosh, M.; Omana, P.K. Very high purity gold from lateritic weathering profiles of Nilambur, southern India. Geology 1991, 19, 746-749. [CrossRef]

57. O'Connor, P.J.; Gallagher, V. Gold prospectivity in the Caledonides of southeast Ireland: Application of the upper-crustal reservoir model. Trans. Inst. Min. Metall. B 1994, 103, 175-187.

58. Alborn, T. An Irish El Dorado: Recovering Gold in County Wicklow. J. Br. Stud. 2011, 50, 359-380. [CrossRef]

59. Spinks, S.C.; Parnell, J.; Bellis, J.; Still, J. Remobilization and mineralization of selenium-tellurium in metamorphosed red beds: Evidence from the Munster Basin, Ireland. Ore Geol. Rev. 2016, 72, 114-127. [CrossRef]

60. Todd, S.P. Taking the roof off a suture zone: Basin setting and provenance of conglomerates in the ORD Dingle Basin of SW Ireland. In New Perspectives on the Old Red Sandstone (Geological Society Special Publication); Friend, P.F., Williams, B.P.J., Eds.; Geological Society of London: London, UK, 2000; Volume 180, pp. 185-222.

61. McArdle, P.; Fitzell, M.; Oosterom, M.G.; O'Connor, P.J.; Kennan, P.S. Tourmalinite as a potential host rock for gold in the Caledonides of Southeast Ireland. Mineral. Depos. 1989, 24, 154-159. [CrossRef]

62. Diskin, S.; Evans, J.; Fowler, M.B.; Guion, P.D. Recognising different sediment provenances within a passive margin setting: Towards characterising a sediment source to the west of the British late Carboniferous sedimentary basins. Chem. Geol. 2011, 283, 143-160. [CrossRef]

63. Chapman, R.J.; Leake, R.C.; Moles, N.R.; Earls, G.; Cooper, C.; Harrington, K.; Berzins, R. The application of microchemical analysis of gold grains to the understanding of complex local and regional gold mineralization: A case study in Ireland and Scotland. Econ. Geol. 2000, 95, 1753-1773.

64. Leake, R.C.; Bland, D.J.; Styles, M.T.; Cameron, D.G. Internal structure of Au-Pd-Pt grains from south Devon, England, in relation to low-temperature transport and deposition. Appl. Earth Sci. 1991, 100, 159-178. 
65. Nekrasov, I.Y.; Ivanov, V.V.; Lennikov, A.M.; Sapin, V.I.; Safronov, P.P.; Oktyabr'skii, R.A. Rare Natural Polycomponent Alloys Based on Gold and Copper from a Platinum Placer in the Konder Alkaline-Ultrabasic Massif, southeastern Aldan Shield, Russia. Geol. Ore Depos. 2001, 43, 406-417.

66. Barkov, A.Y.; Tamura, N.; Shvedov, G.I.; Stan, C.V.; Ma, C.; Winkler, B.; Martin, R.F. Platiniferous tetra-auricupride: A case study from the Bolshoy Khailyk placer deposit, Western Sayans, Russia. Minerals 2019, 9, 160. [CrossRef]

67. Mallet, W. On the minerals of the auriferous districts of Wicklow. J. Geol. Soc. Dublin 1850, 4, 269-277. [CrossRef]

68. Scott, B.G. The occurrence of platinum as a trace element in Irish gold: Comments in Hartmann's gold analyses. Ir. Arch. Res. F. 1976, 3, 21-24.

69. Abdullah, M.H.; Radhid, A.S.A.; Anuar, U.H.M.; Marto, A.; Abuelgasim, R. Bottom ash utilization: A review on engineering applications and environmental aspects. IOP Conf. Ser. Mater. Sci. Eng. 2019, 527, 012006. [CrossRef]

70. Mining.com. Global Coal Production will Grow this Year Despite Covid-19. Available online: https: //www.mining.com/global-coal-production-to-grow-by-0-5-in-2020/ (accessed on 9 June 2020).

71. Yang, L.; Wang, Q.; Bai, X.; Deng, J.; Hu, Y. Mapping of trace elements in coal and ash research based on bibliometric analysis method spanning 1971-2017. Minerals 2018, 8, 89. [CrossRef]

72. Bullock, L.A.; Parnell, J.; Perez, M.; Armstrong, J.T.G.; Feldmann, J.; Boyce, A.J. High selenium in the Carboniferous Coal Measures of Northumberland, North East England. Int. J. Coal Geol. 2018, 195, 61-74. [CrossRef]

73. Bullock, L.A.; Parnell, J.; Perez, M.; Feldmann, J. Tellurium enrichment in Jurassic coal, Brora, Scotland. Minerals 2017, 7, 231. [CrossRef]

74. Dai, S.; Zhao, L.; Peng, S.; Chou, C.-L.; Wang, X.; Zhang, Y.; Li, D.; Sun, Y. Abundances and distribution of minerals and elements in high-alumina coal fly ash from the Jungar Power Plant, Inner Mongolia, China. Int. J. Coal Geol. 2010, 81, 320-332. [CrossRef]

75. Zhang, S.; Liu, G.; Sun, R.; Wu, D. Health risk assessment of heavy metals in groundwater of coal mining area: A case study in Dingji coal mine, Huainan coalfield, China. Hum. Ecol. Risk Assess. Int. J. 2016, 22, 1469-1479. [CrossRef]

76. Fang, T.; Liu, G.; Zhou, C.; Lu, L. Lead in soil and agricultural products in the Huainan Coal Mining Area, Anhui, China: Levels, distribution, and health implications. Environ. Monit. Assess. 2015, 187, 152. [CrossRef] 